\title{
Analisis Kapasitas dan Karakteristik Fasilitas Parkir Fakultas Sains dan Teknologi UIN Sultan Syarif Kasim Riau
}

\author{
Harpito, ST., MT \\ Jurusan Teknik Industri, Fakultas Sains dan Teknologi, UIN Sultan Syarif Kasim Riau \\ Jl. HR. Soebrantas No. 155 Simpang Baru, Panam, Pekanbaru, 28293 \\ Email: harpito@uin-suska.ac.id
}

\begin{abstract}
ABSTRAK
Peningkatan jumlah mahasiswa, dosen dan pegawain di lingkungan Fakultas Sains dan Teknologi UIN Suska Riau berbanding lurus dengan bertambahnya jumlah pengguna kendaraan baik itu kendaraan roda dua maupun kendaraan roda empat. Laju pertumbuhan kendaraan menimbulkan permasalahan dalam sistem perparkiran baik dari segi kapasistas maupun pengelolaan. Untuk mengevaluasi kapasitas dan mengidentifikasi kebutuhan parkir analisis kapasitas dan karakteristik parkir pada fasilitas parkir Fakultas Sains dan Teknologi UIN Suska Riau dilakukan dalam penelitian ini. Survey inventarisasi dan survey kebutuhan parkir dilakukan sebagai data dalam analisis ini. Kebutuhan area parkir mengaju kepada standar satuan ruang parkir (SRP) yang dikeluarkan oleh Ditjen Perhubungan Darat,1996. SRP untuk kendaraan roda-4 yang tersedia di Fakultas Sains dan Teknologi telah memenuhi kebutuhan. SRP yang tersedia adalah $736 \mathrm{~m}^{2}$ dengan kapasitas 64 mobil sedangkan kebutuhan adalah sebesar 471,5 $\mathrm{m}^{2}$ dengan kapasitas 41 mobil. Kelebihan SRP adalah $264,5 \mathrm{~m}^{2}$ dengan kapasitas 23 mobil atau 56,10\%. SRP untuk sepeda motor yang tersedia di Fakultas Sains dan Teknologi belum bahkan jauh kekurangan dari yang dibutuhkan. SRP yang tersedia adalah $300 \mathrm{~m}^{2}$ dengan kapasitas 200 sepeda motor sedangkan kebutuhan adalah sebesar $3.616,5 \mathrm{~m}^{2}$ dengan kapasitas 2.412 sepeda motor. Kekurangan SRP adalah sebesar 3.316,5 $\mathrm{m}^{2}$ dengan kapasitas 2.212 sepeda motor atau 92,70\%. Dengan memanfaatkan semua kawasan Fakultas Sains dan teknologi yang tersedia didapatkan SRP jumlah setelah ditambahkan adalah sebesar $1.260 \mathrm{~m} 2$ dengan kapasitas 840 kendaraan roda-2 atau 34,84\%. Artinya SRP untuk kendaraan roda-2 masih kekurangan sebesar 65,16\%.Pihak fakultas perlu melakukan koordinasi dengan pihak rektorat untuk menentukan kawasan yang bisa dimanfaatkan dalam rangka memenuhui kebutuhan SRP sepeda motor tersebut.
\end{abstract}

Kata Kunci: Kapasitas, Karakteristik, Parkir

\section{Pendahuluan}

Parkir merupakan salah satu komponen suatu sistem transportasi yang perlu dipertimbangkan dalam setiap kebijakan. Selama bepergian kendaraan tidak lepas untuk melakukan kegiatan parkir baik kegiatan bekerja, berdagang, belanja, sekolah, rekreasi dan kegiatan lain (Louis J Pignataro (1973, hal 258). Kegiatan-kegiatan tersebut bisa dibadan jalan (on street parking) dan di luar badan (off street parking).

Fakultas Sains dan Teknologi merupakan fakultas terbesar nomor 2 setelah Fakultas Tarbyah dan Keguruan di UIN Sultan Syarif Kasim Riau. Jumlah mahasiswa di Fakultas Sains dan Teknologi mengalami peningkatan yang sangat signifikan dari tahun ketahun. Peningkatan jumlah mahasiswa ini juga diringi dengan penambahan jumlah dosen dan pegawai. Dengan meningkatnya jumlah mahasiswa, dosen dan pegawai tersebut juga mengakibatkan bertambahnya jumlah pengguna kendaraan baik itu kendaraan roda dua maupun kendaraan roda empat yang membutuhkan area parkir. Laju pertumbuhan kendaraan ini tentunya menimbulkan permasalahan dalam hal perparkiran baik dari segi kapasistas maupun pengelolaan.

UIN Sultan Syarif kasim Riau merupakan salah satu kampus yang mengedepankan prinsipprinsip dasar islam, begitu juga Fakultas sains dan Teknologi. Islam sangat mengajarkan ummatnya untuk mengedepankan keteraturan. Sebagaimana terinspirasi dalam Al-Quran surat al-Shaff ayat (4) yang berbumyi.

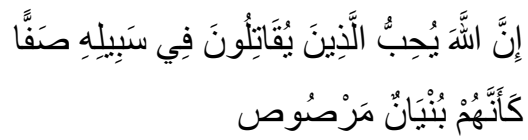


Artinya: Sesungguhnya Allah menyukai orang yang berperang dijalan-Nya dalam barisan yang teratur seakan-akan mereka seperti suatu bangunan yang tersusun kokoh. (Q.S : al-Shaff ayat : 4)

Begitu juga dalam pengelolaan fasilitas perkir kita harus menerapkan prinsip-prinsip keteraturan baik dari segi tempat, waktu maupun jalur kendaraan. Dengan adanya keteraturan ini tentu akan kelihatan lebih rapi dan indah karena sesungguhnya Allah sangat menyukai keindahan. Disamping itu keteraturan ini diharpkan dapat mengoptimalkan lahan dan fasilitas parkir yang ada sehingga dapat termanfaatkan secara efektif dan efisien.

Terdapat masalah umum pada fasilitas parkir di Fakultas Sains dan Teknologi UIN Suska Riau yaitu, tidak termanfaatkannya dengan optimal lahan parkir yang tersedia dan tidak tersedianya fasilitas parkir yang memadai yang berakibat pada tidak nyamannya pengguna parkir di Fakultas Sains dan Teknologi UIN Sultan Syarif Kasim Riau.

Untuk mengatasi permasalahan tersebut perlu kiranya dilakukan evaluasi kapasitas lahan dan fasilitas parkir yang tersedia, identifikasi luas lahan yang dibutuhkan dan fasilitas parkir yang harus disediakan oleh Fakultas Sains dan Teknologi UIN Sultan Syarif Kasim Riau. Sehingga diharapkan dapat membantu memberikan alternatif solusi kepada pihak Fakultas Sains dan Teknologi UIN Sultan Syarif Kasim Riau dalam menyediakan lahan dan fasilitas parkir serta pengelolaan parkir yang dituangkan dalam layout masterplan fasilitas parkir.

\section{Tinjauan Pustaka}

\section{Pengertian}

Menurut PP No. 43 tahun 1993 Tentang Prasarana dan Lalu Lintas Jalan parkir didefinisikan sebagai kendaran yang berhenti pada tempat-tempat tertentu baik yang dinyatakan dengan rambu atau tidak, serta tidak semata-mata untuk kepentingan menaikkan atau menurunkan orang dan atau barang. Menurut Direktorat Jenderal Perhubungan Darat, 1996 Parkir adalah keadaan tidak bergerak suatu kendaraan yang tidak bersifat sementara. Sehingga tempat parkir ini harus ada pada saat akhir atau tujuan perjalanan sudah dicapai. Kebutuhan jumlah parkir mobil, akan berpengaruh secara signifikan terhadap kebutuhan jumlah luasan area parkir, baik itu parkir di dalam gedung, mapun parkir di halaman yang masih tersedia sebagai area terbuka (O’Flaherty, 1997).

\section{Jenis Peruntukan Parkir}

Kebutuhan area parkir berbeda antara yang satu dengan lainnya yang sesuai dengan peruntukkannya. Pada umumnya ada 2 (dua jenis peruntukan kebutuhan parkir, yakni sebagai beirikut (Direktorat Jenderal Perhubungan Darat, 1996):

1. Kegiatan Parkir Tetap
a. Pusat perdagangan
b. Pusat perkantoran swasta atau pemerintah
c. Pusat perdagangan enceran atau pasar swalayan
d. Pasar
e. Sekolah
f. Tempat rekreasi
g. Hotel dan tempat penginapan
h. Rumah sakit

2. Kegiatan Parkir Tetap
a. Bioskop
b. Tempat pertunjukan
c. Tempat pertandingan olahraga
d. Rumah ibadah.

\section{Satuan Ruang Parkir}

Dalam merencanakan sebuah tempat perparkiran yang nyaman maka perlu mengetahui kebutuhan akan ruang parkir. Kebutuhan ruang parkir ditentukan berdasarkan Satuan Ruang Parkir (SRP). Ada berbagai pertimbangan yang diambil untuk menentukan Satuan Ruang Parkir (SRP). Berdasarkan Pedoman Perencanaan dan Pengoperasian Fasilitas Parkir Direktorat Jenderal Perhubungan Darat 1996, hal-hal yang menjadi pertimbangan dalam menentukan satuan ruang parkir adalah:

1. Dimensi Kendaraan Standar Untuk Mobil Penumpang

Dimensi Kendaraan standar untuk mobil penumpang dapat di lihat pada gambar 1

2. Ruang Bebas Kendaraan Parkir

Ruang bebas harus diberikan untuk kendraan yang parkir baik itu pada arah lateral dan longitudinal kendaraan. Ruang bebas dimaksudkan untuk menghindari benturan antara pintu kendaraan dan kendaraan yang parkir di sebelahnya. Ruang bebas arah memanjang diberikan di depan kendaraan untuk menghindari benturan terhadap dinding atau kendaraan yang lewat jalur gang. Jarak bebas arah lateral diambil sebesar $5 \mathrm{~cm}$ dan 
jarak bebas arah longitudinal diambil sebesar $30 \mathrm{~cm}$.

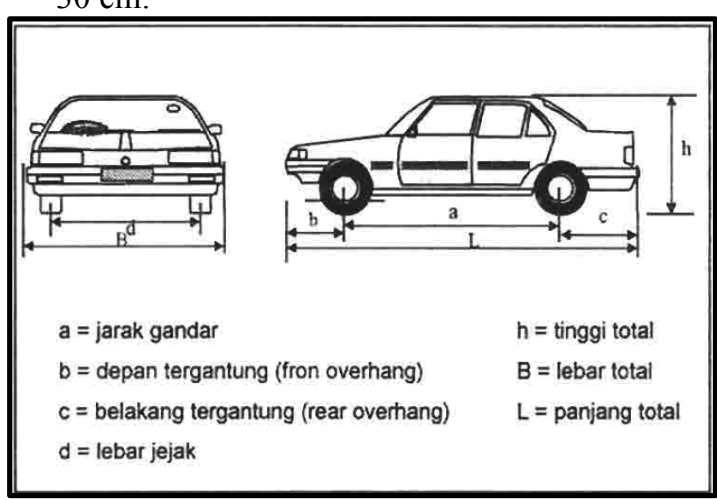

Gambar 1. Dimensi Kendaraan Standar untuk Mobil Penumpang

Sumber: Pedoman Perencanaan dan Pengoperasian Fasilitas Parkir, Direktorat Jenderal Perhubungan Darat

3. Lebar bukaan pintu kendaraan

Ukuran lebar bukaan pintu merupakan fungsi karakteristik pemakai kendaraan yang memanfaatkan fasilitas parkir. Lebar bukaan pintu kendaraan karyawan kantor akan berbeda dengan lebar bukaan pintu kendaraan pengunjung pusat kegiatan perbelanjaan. Karakteristik pengguna kendaraan yang memanfaatkan fasilitas parkir dipilih menjadi tiga seperti yang ditunjukkan dalam Tabel 1 .

Tabel 1. Lebar Bukaan Pintu Kendaraan

\begin{tabular}{|c|c|c|}
\hline $\begin{array}{c}\text { Jenis Bukaan } \\
\text { Pintu }\end{array}$ & $\begin{array}{l}\text { Pengguna dan/atau } \\
\text { peruntukan fasilitas parkir }\end{array}$ & Gol. \\
\hline $\begin{array}{l}\text { Pintu depan / } \\
\text { belakang } \\
\text { terbuka tahap } \\
\text { awal } 55 \mathrm{~cm}\end{array}$ & $\begin{array}{l}\text { - Karyawan/ pekerja kantor } \\
\text { - Tamu/ pengunjung pusat } \\
\text { kegiatan perkantoran, } \\
\text { perdagangan, } \\
\text { pemerintahan, universitas }\end{array}$ & I \\
\hline $\begin{array}{l}\text { Pintu depan / } \\
\text { belakang } \\
\text { terbuka penuh } \\
75 \mathrm{~cm}\end{array}$ & $\begin{array}{l}\text { Pengunjung tempat } \\
\text { olahraga, pusat hiburan/ } \\
\text { rekreasi, hotel, pusat } \\
\text { perdagangan eceran/ } \\
\text { swalayan, rumah sakit, } \\
\text { bioskop. }\end{array}$ & II \\
\hline $\begin{array}{l}\text { Pintu depan } \\
\text { terbuka penuh } \\
\text { dan ditambah } \\
\text { untuk } \\
\text { pergerakan } \\
\text { kursi roda }\end{array}$ & - Orang cacat & III \\
\hline
\end{tabular}

Berdasarkan pertimbangan-pertimbangan di atas maka penentuan Satuan Ruang Parkir (SRP) dibagi menjadi tiga jenis kendaraan dan berdasarkan penentuan SRP untuk mobil penumpang diklasifikasikan menjadi tiga golongan, seperti pada Tabel 2.

Tabel 2. Penentuan Satuan Ruang Parkir (SRP)

\begin{tabular}{|l|c|}
\hline \multicolumn{1}{|c|}{ Jenis Kendaraan } & $\begin{array}{c}\text { Satuan Ruang Parkir } \\
\left(\mathrm{m}^{2}\right)\end{array}$ \\
\hline $\begin{array}{l}\text { 1. a. Mobil Penumpang untuk } \\
\text { Golongan I }\end{array}$ & $2,30 \times 5,00$ \\
\hline $\begin{array}{l}\text { b. Mobil Penumpang untuk } \\
\text { Golongan II }\end{array}$ & $2,50 \times 5,00$ \\
\hline $\begin{array}{l}\text { c. Mobil Penumpang untuk } \\
\text { Golongan III }\end{array}$ & $3,00 \times 5,00$ \\
\hline 2. Bus /truk & $3,40 \times 12,50$ \\
\hline 3. Sepeda motor & $0,75 \times 2,00$ \\
\hline $\begin{array}{l}\text { Sumber: Pedoman Perencanaan } \\
\text { Fasilitas Parkir, Direktorat Jenderal Pengoperasian } \\
\text { Darat Perhubungan }\end{array}$
\end{tabular}

\section{Taman Parkir}

\section{Kriteria Taman Parkir}

Beberapa hal yang perlu dipertimbangkan dalam mendisain taman parkir dan yang merupakan kriteria yang digunakan sebagai dasar dalam mendisain tempat/pelataran parkir aalah sebagai berikut (Direktorat Jenderal Perhubungan Darat, 1996):

1. Rencana Umum Tata Ruang Daerah (RUTRD)

2. Keselamatan dan kelancaran lalulintas

3. Kelestarian lingkungan

4. Kemudahan bagi pengguna jasa

5. Ketersedaiaan tata guna lahan

6. Letak antara jalan akses utama dan daerah yang dilayani.

\section{Pola Parkir Mobil Penumpang}

1. Parkir Kendaraan Satu Sisi Pola Parkir ini diterapkan apabila ketersediaan ruang sempit di suatu tempat kegiatan.

a. Membentuk Sudut $90^{\circ}$

Pola Parkir ini mempunyai daya tampung lebih banyak jika dibandingkan dengan pola parkir paralel, tetapi kemudahan dan kenyamanan pengemudi melakukan manuver masuk dan keluar ruang parkir lebih sedikit jika dibandingkan dengan pola parkir dengan sudut yang lebih kecil dari $90^{\circ}$.

b. Membentuk Sudut $30^{\circ}, 45^{\circ}, 60^{\circ}$

Pola parkir ini mempunyai daya tampung lebih banyak jika dibandingkan dengan pola parkir paralel dan kemudahan dan kenyamanan pengemudi melakukan manuver masuk dan keluar ke ruang parkir lebih besar jika dibandingkan dengan pola parkir dengan sudur $90^{\circ}$. 
2. Parkir Kendaraan dua Sisi

Pola parkir ini diterapkan apabila ketersediaan ruang cukup memadai

a. Membentuk Sudut $90^{\circ}$

Pada pola parkir ini arah gerakan lalulintas kendaraan dapat satu arah atau dua sisi.

b. Membentuk Sudut $30^{\circ}, 45^{\circ}, 60^{\circ}$

Pada pola ini kemudahan dan kenyamanan pengemudi melakukan manuver masuk dan keluar ke ruang parkir lebih besar jika dibandingkan dengan pola parkir dengan sudur $90^{\circ}$

3. Pola Parkir Pulau

Pola parkir ini diterapkan apabila ketersediaan ruang cukup luas.

a. Membentuk sudut $90^{\circ}$

Pola parkir ini hampir mirip dengan pola parkir dua sisi membentuk sudut $90^{\circ}$, hanya saja pada jenis ini tetdapat dua gang

b. Membentuk sudut $45^{\circ}$ bentuk tulang ikan tipe-A

c. Membentuk sudut $45^{\circ}$ bentuk tulang ikan tipe-B

d. Membentuk sudut $45^{\circ}$ bentuk tulang ikan tipe-C

\section{Pola Parkir Sepeda Motor}

Pada umumnya pola parkir sepeda motor menggunakan pola parkie dengan sudut 90o. Dari segi efektifitas ruang untuk sepeda motor posisi 90o paling menguntungkan.

1. Pola Parikir satu sisi

Pola ini digunakan apabila ketersediaan ruang sempit

2. Pola Parkir dua sisi

Pola ini di terapkan apabila ketersediaan ruang cukup memadai (lebar ruas $>5,60 \mathrm{~m}$ )

3. Pola Parkir Pulau

Pola ini diterapkan apabila ketersediaan ruang cukup luas.

\section{Jalur Sirkulasi, Gang dan Modul}

Perbedaan antara jalur sirkulasi dan jalur gang terutama terletak pada penggunaannya. Patokan umum yang dipakai adalah (Ditjend. Perhubungan Darat, 1996):

a. Panjang sebuah jalur gang tidak lebih dari 100 meter

b. Jalur gang yang ini dimaksudkan untuk melayani lebih dari 50 kendaraan dianggap sebagai jalur sirkulasi;

c. Lebar jalur sirkulasi untuk jalan satu arah = 3,5 meter

d. Lebar jalur sirkulasi untuk jalan dua arah = 6,5 meter.

\section{Metodologi Penelitian}

\section{Metoda Survey}

Survey utama yang dilakukan dalam studi perparkiran pada lahan dan fasilitas parkir Fakultas Sains dan Teknologi UIN Sultan Syarif Kasim Riau ini mencakup survey inventaris parkir dan survey kebutuhan parkir. Hal ini untuk memperoleh data penyediaan parkir (supply) dan kebutuhan parkir (demand) pada lahan dan fasilitas parkir Fakultas Sains dan Teknologi UIN Sultan Syarif Kasim Riau:

\section{Survey Inventarisasi Ruang Parkir}

Pelaksanaan survey inventarisasi ruang parkir bertujuan untuk mengetahui kapasitas dan fasilitas ruang parkir yang tersedia (kondisi eksisting). Survey inventarisasi ini dilakukan dengan melihat hal-hal sebagai berikut:

1. Lokasi Perparkiran Fakultas Sains dan Teknologi UIN Sultan Syarif Kasim Riau

2. Jenis ruang parkir

3. Jumlah ruang parkir yang tersedia

4. Pengaturan arus lalu lintas atau jalur sirkulasi kendaraan.

\section{Survey Kebutuhan Parkir}

Survey dilakukan dengan cara mencatat jumlah kendaraan yang masuk dan keluar pada lokasi perparkiran atau biasa disebut dengan metode teknik keluar masuk. Keuntungan metode ini adalah sebagai berikut:

1. Dapat mengukur akumulasi kendaraan, terutama pada puncak-puncak akumulasi agar dapat menentukan prosentase dari kapasitas parkir yang sedang digunakan pada saat itu.

2. Dapat mengukur total kapasitas ruang parkir per jam yang dibutuhkan dalam 1 hari.

\section{Metoda Pengolahan Data}

Data - data yang akan dianalisis adalah data yang diperoleh dari hasil pelaksanaan survey inventarisasi dan survey kebutuhan parkir. Dari data tersebut akan disusun dan disajikan sedemikian rupa sehingga dapat diproses untuk di analisis.

\section{Data Inventarisasi Parkir}

Data inventarisasi parkir pada area parkiran Fakultas Sains dan Teknologi UIN Sultan Syarif Kasim Riau yang diperoleh dari hasil survey adalah : 
1. Denah lokasi perparkiran (Layout)

2. Jenis ruang parkir

3. Pengaturan arus lalu lintas parkir

4. Fasilitas parkir

5. Prilaku parkir

\section{Data Kebutuhan Parkir}

Bentuk data umum hasil survey lapangan tentang kebutuhan parkir didapat melalui survey yang dilakukan dan akan disusun dengan dengan sistem komputerisasi. Data tersebut berupa jumlah kedaraan, waktu masuk, waktu keluar serta lamanya kendaraan tersebut parkir.

Kegiatan yang perlu dilaksanakan sebelum melakukan kegiatan survey antara lain:

1. Pengamatan lokasi parkir, yaitu untuk mengamati posisi pintu masuk dan pintu keluar. Lokasi tersebut akan menjadi tempat surveyor berada dalam rangka melakukan survey.

2. Menyiapkan formulir yang sekiranya mudah dimengerti dan digunakan oleh para surveyor untuk mencatat data yang dibutuhkan

3. Mempersiapkan alat-alat survey yang diperlukan.

Adapun cara pelaksanaan survey yang dilakukan dalam penelitian ini adalah sebagai berikut:

1. Pada awal pelaksanaan survey, dilakukan pencatatan dan penghitungan terlebih dahulu terhadap jumlah seluruh kendaraan yang telah diparkir dan berada dalam daerah pengamatan.

2. Survey dilaksanakan pada hari kerja (hari kuliah) yaitu hari senin s/d hari jumat terutama pada jam-jam sibuk.

3. Pelaksanaan survey dibagi menjadi 2 (dua) sift yaitu sif pagi dan sift siang.

4. Sift pagi dilakukan pada pukul 09.00 WIB sampai dengan pukul $10.00 \mathrm{WIB}$, sedangkan sift siang dilakukan pada puku 14.00 WIB sampai dengan pukul 15.00 WIB.

\section{Hasil Dan Pembahasan}

\section{Inventarisasi Area Parkir}

Untuk merencanakan lahan parkir di perlukan informasi mengenai karakteristik parkir yang terjadi pada kondisi eksisting lahan parkir yang tersedia. Karaktersitik parkir meliputi, volume parkir, akumulasi parkir, durasi parkir, angka pergantian parkir, kapasitas parkir (Tamin, 2002)

\section{Lokasi Parkir}

Lokasi parkir yang menjadi objek penelitian adalah area parkir yang secara mutlak milik Fakultas Sains dan Teknologi. Sedangkan area parkir yang dipakai bersama dengan fakultas lain tidak diperhitungkan. Pembatasan ini perlu dilakukan mengingat sulitnya menetukan batas pemakaian area parkir antara Fakultas Sains dan Teknologi dengan fakultas lain. Disamping itu juga akan berpengaruh terhadap sistem informasi dan sistem keamanan yang akan diterapkan.

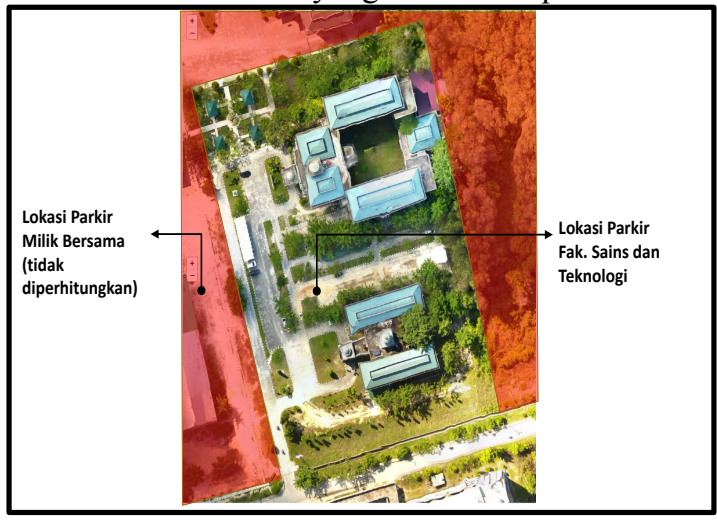

Gambar 2 Lokasi parkir fak. sains dan teknologi

\section{Jenis dan Kapasitas Ruang Parkir}

Jenis ruang parkir yang ada di Fakultas Sains dan Teknologi adalah ruang parkir berupa taman parkir yang terletak disekitaran gedung Fakultas Sains dan Teknologi. Meskipun demikian beberapa kendaraan juga ada yang terlihat parkir di badan jalan (on street parking). Pola parkir yang gunakan adalah pola parkir $90^{\circ}$.

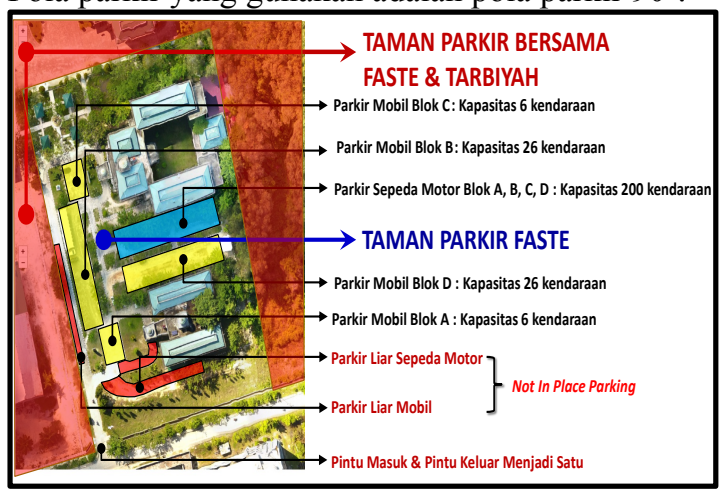

Gambar 3 Eksiting taman parkir fak. sains dan teknologi

Kapasitas ruang parkir yang tersedia disajikan dalam tabel berikut: 
Tabel 3. SRP Existing mobil

\begin{tabular}{|c|c|c|c|}
\hline No. & Blok & SRP $\left(\mathrm{m}^{2}\right)$ & $\begin{array}{c}\text { Kapasitas. (RODA- } \\
4)\end{array}$ \\
\hline 1 & A & 69 & 6 \\
\hline 2 & B & 299 & 26 \\
\hline 3 & C & 69 & 6 \\
\hline 4 & D & 299 & 26 \\
\hline \multicolumn{2}{|l}{ TOTAL } & $\mathbf{7 3 6}$ & $\mathbf{6 4}$ \\
\hline
\end{tabular}

Sumber: Pengolahan data 2017

Tabel 4. SRP Existing sepeda motor

\begin{tabular}{|c|c|c|c|}
\hline $\begin{array}{c}\text { No } \\
\cdot\end{array}$ & BLOK & SRP $\left(\mathrm{m}^{2}\right)$ & $\begin{array}{c}\text { Kapasitas. (RODA- } \\
\text { 2) }\end{array}$ \\
\hline 1 & A & 75 & 50 \\
\hline 2 & B & 75 & 50 \\
\hline 3 & C & 75 & 50 \\
\hline 4 & D & 75 & 50 \\
\hline \multicolumn{2}{|r|}{ TOTAL } & $\mathbf{3 0 0}$ & $\mathbf{2 0 0}$ \\
\hline
\end{tabular}

Sumber: Pengolahan data 2017

\section{Pengaturan Arus Lalu Lintas dan Jalur Sirkulasi}

Area parkir Fakultas Sains dan Teknologi memiliki satu pintu masuk yang sekaligus merupakan pintu keluar (pintu masuk menjadi satu dengan pintu keluar) dengan jarak pintu masuk yang sangat dekat dengan persimpangan. Kondisi ini menyebabkan sering terjadi kemacetan di depan pintu masuk dan/atau pintu keluar area parkir ketika terjadi konflik antara kendaraan yang akan masuk dan yang akan keluar area parkir.

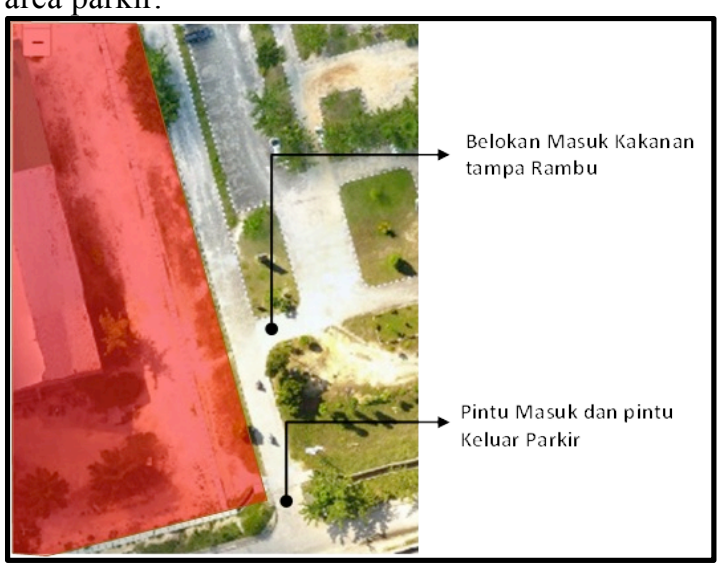

Gambar 4 Jalur sirkulasi parkir fak. sains dan teknologi

Menurut

Pedoman

Teknis

Penyelenggaraan Fasilitas Parkir Ditjen Perhubungan darat ukuran lebar pintu keluarmasuk dapat ditentukan, yaitu lebar 6.0 meter untuk dua jalur dan panjangnya harus dapat menampung tiga mobil berurutan dengan jarak antar mobil (spacing) sekitar 1,5 meter. Hal-hal yang harus diperhatikan dalam merencanakan pintu masuk menurut Pedoman Teknis Penyelenggaraan Fasilitas Parkir Ditjen Perhubungan darat adalah:

1. Letak jalan masuk/keluar ditempatkan sejauh mungkin dari persimpangan

2. Letak jalan masuk/keluar ditempatkan sedemikian rupa sehingga kemungkinan konflik dengan pejalan kaki dan yang lain dapat dihindarkan.

3. Letak jalan keluar ditempatkan sedemikian rupa sehingga memberikan jarak pandang yang cukup saat memasuki arus lalu lintas.

4. Secara teoretis dapat dikatakan bahwa lebar jalan masuk dan keluar (dalam pengertian jumlah jalur) sebaiknya ditentukan berdasarkan analisis kapasitas.

\section{Kebutuhan Parkir}

SRP untuk mobil penumpang adalah 2,3m x 5,0m (Ditjen Perhubungan Darat, 1998). Jumlah maksimum mobil penumpang yang parkir di area parkir Fakultas Sains dan Teknologi adalah 41 kendaraan perhari, data hasil survey terlampir pada lampiran-1. SRP untuk mobil penumpang yang tersedia adalah $736 \mathrm{~m}^{2}$ atau dengan kapasitas 64 kendaraan. Data tersebut memperlihatkan bahwa SRP untuk mobil penumpang telah memenuhi bahkan melebihi kebutuhan. Kelebihan ini tetap kita pertahankan sebagai langkah antisipasi jika sewaktu-waktu ada even di Fakultas Sains dan Teknologi yang membutuhkan SRP yang lebih besar.

SRP untuk sepeda motor adalah $0,75 \mathrm{~m} \mathrm{x}$ 2,0m (Ditjen Perhubungan Darat, 1998). Kebutuhan parkir sepeda motor adalah 2.412 kendaraan atau dengan SRP sebesar $3.616,5 \mathrm{~m}^{2}$. SRP sepeda motor yang tersedia di Fakultas Sains dan Teknologi saat ini adalah $300 \mathrm{~m}^{2}$ dengan kapasitas 200 kendaraan atau hanya 8,30\%. Dengan demikian, Fakultas Sains dan Teknologi membutuhkan tambahan SRP kendaraan roda-2 sebesar $3.616,5 \mathrm{~m}^{2}-300 \mathrm{~m}^{2}=3.316,5 \mathrm{~m}^{2}$ dengan kapasitas 2.211 sepeda motor atau 92,70\%. Penambahan SRP ini dilakukan dengan memanfaatkan area yang ada dikawasan Fakulas Sains dan Teknologi. Penambahan SRP ini tentunya juga diiringi dengan penambahan jalur sirkulasi.

Penambahan SRP yang dapat dilakukan adalah $960 \mathrm{~m}^{2}$ dengan kapasitas 640 sepeda motor. Dengan penambahan tersebut maka SRP total sepeda motor yang dapat disediakan sebesar $1.260 \mathrm{~m}^{2}$ dengan kapasitas 840 sepeda motor atau $34,84 \%$. Dibandingkan dengan kebutuhan yatu sebesar $3.316,5 \mathrm{~m}^{2}$ dengan kapasitas 2.212 sepeda 
motor, SRP sepeda motor masih devisit sebesar $2.356,5 \mathrm{~m}^{2}$ dengan kapsitas 1.571 sepeda motor atau $65,16 \%$. Kondisi penambahan ini telah memamfaatkan seluruh kawasan yang mungkin untuk dijadikan area parkir Fakultas Sains dan teknoogi seperti yang disajikan pada gambar 5 . Untuk memenuhi kebutuhan SRP sepeda motor tersebut maka pihak fakultas perlu mengkoordinasikan dengan pihak rektorat mengenai kawasan mana yang bisa di manfaatkan oleh Fakultas Sains dan Teknologi sebagai area parkir.

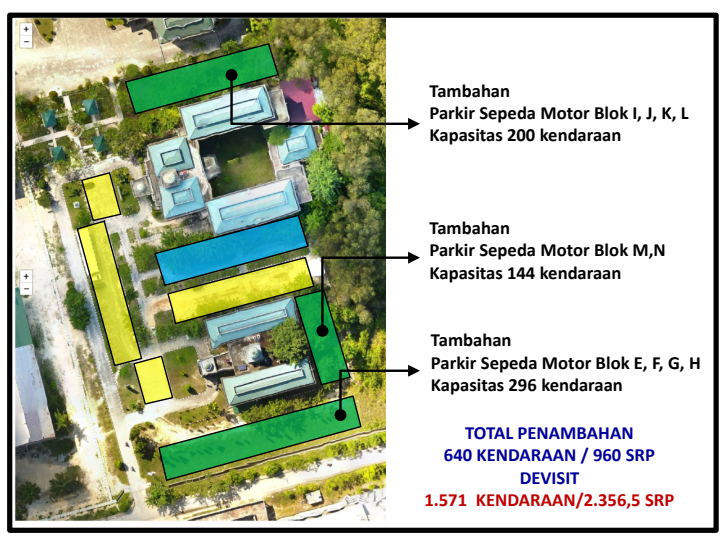

Gambar 5. Penambahan area parkir sepeda motor

\section{Fasilitas dan Perilaku Pengguna Parkir}

Selain permasalahan SRP, permasalahan lain yang kita temukan di lapangan adalah minimnya fasilitas parkir (poor parking facilities). Minimnya fasilitas dapat kita lihat dari tidak ada nya rambu dan marka parkir, tidak adanya sistem informasi dan sistem keamanan parkir, serta masih banyaknya kita temukan perkerasan area parkir yang berlubang dan tergenang air ketika hujan. Poor parking facilities secara langsung mempengaruhi perilaku pengguna parkir dimana pengguna parkir enggan untuk memarkirkan kendaraannya di area poor parking facilities. Efeknya, pengguna parkir cenderung memearkirkan kendaraannya di daerah telarang (not in place parking). Hal ini sering menimbulkan konflik parkir dan mengakibatkan terjadinya penyempitan jalan dan jalur sirkulasi parkir. Untuk mengatasi permasalahan ini pemangku kebijakan perlu dan harus memikirkan penyediaan fasilitas parkir yang memadai.

\section{Kesimpulan}

SRP untuk mobil penumpang yang tersedia di Fakultas Sains dan Teknologi telah memenuhi kebutuhan. SRP yang tersedia adalah $736 \mathrm{~m}^{2}$ dengan kapasitas 64 mobil penumpang sedangkan kebutuhan adalah sebesar $471,5 \mathrm{~m}^{2}$ dengan kapasitas 41 mobil penumpang. Kelebihan SRP adalah $264,5 \mathrm{~m}^{2}$ dengan kapasitas 23 mobil penumpang atau $56,10 \%$.

SRP untuk kendaraan sepeda motor yang tersedia di Fakultas Sains dan Teknologi belum memnuhi kbutuhan bahkan jauh kekurangan dari yang dibutuhkan. SRP yang tersedia adalah $300 \mathrm{~m}^{2}$ dengan kapasitas 200 sepeda motor sedangkan kebutuhan adalah sebesar $3.616,5 \mathrm{~m}^{2}$ dengan kapasitas 2.412 sepeda motor. Kekurangan SRP adalah sebesar $3.316,5 \mathrm{~m}^{2}$ dengan kapasitas 2.212 sepeda motor atau 92,70\%.

Penambahan SRP sepeda motor dengan memanfaatkan sepenuhnya area yang ada dikawasan Fakultas Sains dan Teknologi belum mampu menutupi kekurangan SRP sepeda motor sesuai dengan yang dibutuhkan. Jumlah SRP setelah ditambahkan adalah sebesar $1.260 \mathrm{~m}^{2}$ dengan kapasitas 840 sepeda motor atau 34,84\%. Artinya SRP untuk sepeda motor masih kekurangan sebesar $65,16 \%$.

Pihak-pihak yang berwenang perlu melakukan koordinasi untuk mengambil kebijakan penambahan area parkir dalam rangka memenuhi kebutuhan SRP sepeda motor.

\section{Daftar Pustaka}

[1] Al-Qur'an dan Terjemahannya Edisi Baru Revisi, Departemen Agama RI, Semarang: CV.TOHA PUTRA, 1976

[2] Direktorat Jenderal Perhubungan Darat. Pedoman Teknis Penyelenggaraan Fasilitas Parkir. Jakarta : Dit BSLLAK, 1996

[3] Direktorat Jenderal Perhubungan Darat. Perencanaan dan Pengoperasian Fasilitas Parkir. Jakarta : Dit BSLLAK, 1998

[4] Dirganakbari. Mh. I, Hayati. N. Nuring, Suyoso. H Penyediaan Fasilitas Parkir Di Pusat Perbelanjaan Roxy Square Kabupaten Jember, 2015

http://journal.unpar.ac.id/index.php/journaltr ansportasi/article/view/1851

[5] Munawar, A. Dasar-Dasar Teknik Transportasi. Yogyakarta: Beta Offset, 2005

[6] O'Flaherty, C. A. Transport Planning and Traffic Engineering 4th edition. Edmonton: Arnold Publishing, 1997

[7] Oppenlander, J.C. and Box P.C. Manual of Traffic Engineering Studies, 4th edition, Institute of Transportation Engineering Washington DC, 1976

[8] Suthanaya, Putu. A. Analisis Karakteristik Dan Kebutuhan Ruang Parkir Pada Pusat Perbelanjaan Di Kabupaten Badung. Jurnal Ilmiah Teknik Sipil Vol. 14, No. 1, Januari 
2010 Fakultas Teknik Universitas Udayana Denpasar, 2010

[9] Tamin, O. Z. Perencanaan dan Pemodelan Transportasi. Bandung: Institut Teknologi Bandung, 2002

[10] Warpani, S. Merencanakan Sistem Perangkutan. Bandung: Institut Teknologi Bandung, 1990 